\title{
KOMUNIKASI PEMBANGUNAN PEMERINTAHAN GAMPONG DALAM PERENCANAAN PENGELOLAAN DANA ANGGARAN PENDAPATAN DAN BELANJA GAMPONG (APBG)
}

(Studi di Gampong Pelita Sagoup Jaya, Kecamatan Indra Makmur, Kabupaten Aceh Timur)

\author{
Muhammad Ali ${ }^{1}$ \& Antika Widiana \\ muhammad.ali@unimal.ac.id \\ 1. Dosen Program Studi Ilmu Komunikasi Universitas Malikussaleh
}

\begin{abstract}
Absstrak
Penelitian ini dilator belakangi oleh komunikasi pembangunan yang dijalankan oleh pemerintah gampong belum maksimal dan belum transparan dalam mengkomunikasikan tentang perencanaan dan pengelolaan dana anggaran pendapatan dan belanja gampong sehingga ini menghambat tercapainya tujuan komunikasi pembangunan yang efektif. Penelitian ini bertujuan adalah untuk mengetahui komunikasi pembangunan yang dijalankan pemerintah gampong dan hambatan komunikasi apa yang dihadapi pemerintah gampong dalam menjalankan komunikasi pembangunan tentang perencanaan pengelolaan dana APBG. Metode penelitian yang digunakan adalah metode penelitian kualitatif bersifat deskriptif. Teknik pengumpulan data dalam penelitian ini adalah wawancara, observasi dan dokumentasi. Hasil penelitian ini menunjukan bahwa komunikasi pembangunan yang dijalankan oleh pemerintah gampong adalah komunikasi yang dijalankan secara langsung seperti musyawarah dusun, musyawarah gampang, rapat-rapat internal dan komunikasi menggunakan media seperti spanduk, baliho, dan papan proyek. Selain itu hambatan komunikasi pembangunan yang dihadapi pemerintah gampong Pelita Sagoup Jaya, berupa kepentingan, prasangka, dan motivasi.
\end{abstract}

Kata Kunci: Komunikasi Pembangunan, Pemerintah Gampong, Dana Anggaran Pendapatan dan Belanja Gampong (APBG)

\section{Pendahuluan}

Gampong sebagai unit organisasi pemerintah yang berhadapan langsung dengan masyarakat dengan segala latar belakang kepentingan dan kebutuhannya mempunyai peranan yang 
sangat strategis. Maka desentralisasi kewenangan-kewenangan yang lebih besar disertai dengan pembiayaan dan bantuan sarana dan prasarana yang memadai serta komunikasi yang dilakukan pemerintahan gampong mutlak diperlukan guna penguatan otonomi gampong menuju kemandirian gampong. Dalam melakukan penguatan otonomi gampong, maka setiap gampong memiliki perencanaan tentang Anggaran Pendapatan Dan Belanja Gampong (APBG), yang mana anggaran ini terdiri atas bagian pendapatan gampong, belanja gampong, dan pembiayaan.

Dalam meningkatkan suatu perencanaan dalam pengelolaan dana APBG (Anggaran Pendapatan dan Belanja Gampong) terhadap pembangunan maka pemerintahan gampong memegang peranan penting untuk berinteraksi dan berkomunikasi kepada masyarakat tentang perencanaan pada pengelolaan dana APBG terhadap pembangunan. Tujuannya ialah agar masyarakat mengetahui dan memahami manfaat dan kegunaan pembangunan tersebut. Maka dari itu dalam sebuah gampong diperlukan adanya komunikasi pembangunan yang dilakukan oleh pemerintah gampong.

Menurut Iskandar, S.pd selaku ketua JARA Pidie dan pidie Jaya, Aceh dikutip dalam Serambinews.com menyatakan bahwa "Keuchik/kepala desa sebagai pengguna anggaran juga wajib melaksanakan amanah UU Nomor 14 tahun 2008 tentang Keterbukaan Informasi Publik (KIP). Sesuai pasal 3 ayat (a), yang menjamin hak warga negara untuk mengetahui rencana pembuatan kebijakan publik. Kucuran dana dari pemerintah pusat untuk desa pada hakikatnya adalah untuk mempercepat pembangunan desa dalam meningkatkan kesejahteraan masyarakat itu desa sendiri. Namun, dalam pelaksanaannya, pengelolaan anggaran desa ini banyak yang tidak transparan dan diselewengkan" (http://aceh .tribunnews.com /2016/03/ 20/ polisi-diminta -usut-penyimpanganapbg/diakses pada 15 Maret 2018).

Komunikasi pembangunan merupakan suatu ilmu yang mengajarkan bagaimana komunikasi harus dilakukan, sehingga komunikasi tersebut bisa berperan dan menunjang perencanaan dan program-program pembangunan dalam rangka menciptakan perubahan pada suatu sistem sosial. Maka dari itu, tanpa komunikasi yang efektif maka pencapaian tujuan pembangunan akan rendah. Komunikasi pembangunan dilakukan tidak hanya 
untuk pembangunan yang ada di perkotaan, melainkan juga pembangunan yang ada dipedesaan.

Komunikasi pembangunan yang dilakukan pemerintahan gampong merupakan penyampaian ide, program, dan gagasan pembangunan dalam rangka mencapai tujuan pembangunan. Pemerintahan gampong yang terdiri dari, keuchik, bendahara gampong, sekretaris gampong, dan perangkat gampong lainnya sebagai komunikator juga merupakan komponen sumber daya manusia sehingga perlu ditingkatkan kemampuan profesionalnya.

Pemerintahan gampong khususnya bagi keuchik selaku kepala gampong harus selalu memberikan motivasi serta masukanmasukan dan dukungan kepada pemerintahan gampong untuk berperan aktif dalam mendorong masyarakat untuk senantiasa memahami proses perencanaan terhadap pengelolaan APBG di gampong. Peran pemerintahan gampong dalam komunikasi pembangunan merupakan sebuah kunci keberhasilan pada suatu pembangunan bangsa dan negara. Tanpa adanya komunikasi diantara perencanaan dan sarana pembangunan, pembangunan tidak akan berhasil seperti yang diharapkan. Pemerintahan gampong tidak hanya sekedar memfasilitasi masyarakat dengan pembangunan fisik saja, melainkan juga melalui pembinaan sosial. Sebab implementasi pembangunan harus mampu mengkomodir dan menjawab masalah dan kebutuhan masyarakat. Pemerintahan gampong yang sadar akan kompetensi dan tugasnya serta peka terhadap perubahan lingkungan dan menyadari adanya komunikasi akan memperoleh pengalaman dalam menyusun kebijakan dan strategi yang dapat memberi solusi yang tepat.

Melihat pentingnya peran pemerintahan gampong dalam hal pembangunan baik itu secara fisik maupun non fisik di Gampong Pelita Sagoup Jaya, Kecamatan Indra Makmu, Kabupaten Aceh Timur, maka dari itu perlu adanya komunikasi pembangunan yang dilakukan oleh pemerintahan gampong untuk meningkatkan kerja sama antara pemerintahan gampong dengan masyarakat dalam perencanaan pengelolaan dana APBG untuk pembangunan.

Berdasarkan observasi awal peneliti terhadap gampong yang menjadi rencana penelitian tersebut menunjukan permasalahan bahwa komunikasi yang dilakukan oleh pemerintahan gampong di Gampong Pelita Sagoup Jaya, Kecamatan Indra Makmu dalam perencanaan pengelolaan dana APBG untuk pelaksanaan pembangunan belum dapat dikatakan 
terbuka dan transparan dalam melakukan komunikasi pembangunan kepada masyarakat. Selain itu penggunaan media komunikasi yang dilakukan oleh pemerintahan gampong seperti papan pengumuman dan spanduk yang berisi tentang data-data pengeluaran dana APBG juga masih kurang mendapatkan perhatian dari masyarakat, yang memang mayoritas masyarakat yang ada di gampong tersebut adalah masyarakat yang memiliki minat baca yang kurang terutama terkait dengan dana APBG.

Dalam observasi awal juga peneliti melihat adanya hambatan yang terjadi pada pemerintahan gampong saat menyampaikan informasi terkait dengan dana APBG yaitu hambatan komunikasi meliputi kepentingan, prasangka, dan motivasi baik itu dari pemerintah gampong maupun dari masyarakat gampong. Melihat hal diatas dapat diketahui bahwa tujuan dari komunikasi pembangunan yang dilakukan oleh pemerintahan gampong melalui media atau tidak dengan media belum tersampaikan dengan baik, sehingga masih ada persepsi dari masyarakat tidak sesuai dengan tujuan komunikasi pembangunan yang dilakukan oleh pemerintahan Gampong terkait dengan APBG.

\section{Komunikasi Pembangunan}

Konsep komunikasi pembangunan dapat dilihat dalam arti yang luas dan terbatas. Dalam arti yang luas, komunikasi pembangunan meliputi peran dan fungsi komunikasi (sebagai suatu aktivitas pertukaran pesan secara timbal-balik) di antara semua pihak yang terlibat dalam usaha pembangunan terutama antara masyarakat dengan pemerintah, sejak dari proses perencanaan, kemudian pelaksanaan, dan penilaian terhadap pembangunan. Sedangkan dalam arti sempit, komunikasi pembangunan merupakan segala upaya dan cara, serta teknik penyampaian gagasan, dan keterampilan-keterampilan pembangunan yang berasal dari pihak yang memprakarsai pembangunan dan ditujukan kepada masyarakat luas. Kegiatan tersebut bertujuan agar masyarakat yang dituju dapat memahami, menerima, dan berpartisipasi dalam melaksanakan gagasan-gagasan yang disampaikan (Nasution, 2007: 105-106).

Pengertian komunikasi pembangunan yang dikemukakan oleh Quebral dan Gomez (1979) dalam (Nasution, 2007:142) mengatakan, bahwa komunikasi pembangunan merupakan disiplin ilmu dan praktikum komunikasi dan konteks negara-negara sedang 
berkembang, terutama kegiatan komunikasi untuk perubahan sosial yang berencana. Secara pragmatis, kata Quebral dapat dirumuskan bahwa komunikasi pembangunan adalah komunikasi yangdilakukan untuk melaksanakan rencana pembangunan suatu negara.

Pengertian komunikasi pembangunan (developmental communication) menurut Widjaja A.W dan Hawab dalam (Dilla, 2007:115) adalah komunikasi yang berisi pesan-pesan pembangunan. Maksudnya, komunikasi pembangunan ada pada segala macam tingkatan, dari petani sampai pejabat, pemerintahdan negara, termasuk didalamnya dapat berbentuk pembicaran kelompok, musyawarah pada lembaga resmi siaran, dan lain sebagainya. Dengan demikian, dapat dikatakan bahwa komunikasi pembangunan merupakan suatu inovasi yang diterima oleh masyarakat melalui proses komunikasi.

Menurut (Dilla, 2007:120) komunikasi pembangunan pada dasarnya melibatkan minimal tiga komponen yaitu, yang pertama adalah komunikator pembangunan, yakni bisa pemerintah atau masyarakat yang bertujuan membangun. Kedua adalah pesan pembangunan, yakni ide-ide ataupun program pembangunan. Ketiga adalah komunikan pembangunan, yakni masyarakat secara luas. Dengan demikian usaha-usaha pembangunan seharusnya diwujudkan dengan konsep yang berpusat pada masyarakat. komunikasi dalam konteks ini harus berada di depan untuk merubah sikap dan manusia sebagai pemeran utama pembangunan baik sebagai subjek pembangunanmaupun objek pembangunan.

\section{Jenis -jenis Komunikasi dalam Pembangunan}

1. Komunikasi Tatap Muka (face to face) adalah komunikasi yang dilakukan oleh dua orang atau lebih dengan cara komunkasi secara langsung (bertemu/tatap muka) tanpa melalui perantaraan atau media apapun. Komunikasi face to face ini adalah komunikasi yang dilakukan dimana komunikator berhadapan langsung dengan komunikannya dan memungkinkan respon yang langsung dari keduanya. Artinya komunikator dalam penyampaian informasi-informasi baru mengenai pelaksanaan pembangunan dapat menyampaikan secara langsung kepada komunikannya sehingga adanya respon yang langsung dari keduanya. 
2. Komunikasi bermedia adalah komunikasi yang menggunakan media seperti handphone, surat, komputer, microphone mesjid, spanduk dan lainnya. Contohnya saat ingin mengirimkan pesan/informasi kepadamasyarakat dan perangkat gampong menggunakan media-media tersebut. Komunikasi bermedia merupakan unsur yang sangat penting dalam proses komunikasi, dengan menggunakan media maka komunikasi aliran informasi berita atau pesan dapat dikirim atau diterima dengan mudah dan cepat. Berdasarkan jangkauannya komunikasi dalam bermedia terdapat dua jenis yaitu:

1. Media komunikasi eksternal merupakan suatu media komunikasi yang dipakai untuk menjalin hubungan dan menyampaikan pesan informasi dengan pihak-pihak luar, misalnya: Media komunikasi tertulis/cetak, radio, televisi/TV, telepon, telepon selular (Handphone), surat dan internet.

2. Media komunikasi internal ialah seluruh sarana penyampaian dan penerimaan pesan informasi dikalangan publik internal, dan pada umumnya mempunyai sifat nonkomersial. Penerima atau pengirim informasinya adalah orang-orang publik internal. Media yang bisa dipakai sebagai komunikasi internal yaitu, seperti: surat. Telephone, papan pengumuman, majalah bulanan, media komunikasi cetakan (printed material), media pertemuan dan pembicaraan, dll.

\section{Peran-Peran Baru Komunikasi Pembangunan}

a. Komunikasi dan pembangunan kapasitas diri

Rogers (1976) dalam (Dilla, 2007:132) menyarankan bahwa untuk mengatasi permasalahan pembangunan yaitu semestinya ide pembangunan tersebut dimulai dari dalam masyarakat dalam pembangunan kapasitas dirinya. Yang dimaksud kapasitas diri yaitu partisipasi, sosialisasi, kerjasama, dan tanggung jawab di antara individu-kelompok dalam perencanaan pembangunan.

b. Memanfaatkan media rakyat (folk media) dalam Pembangunan

Media rakyat adalah suatu kebudayaan yang ada dalam suatu masyarakat tertentu, biasanya mempunyai ragam bentuk seperti teater rakyat, pewayangan, tarian rakyat, balada, dll. Penggunaan media rakyat sebagai alternatif yang relevan bagi pembangunan didasarkan oleh beberapa alasan, yaitu: minimnya 
pengetahuan dan keterampilan, status sosial ekonomi yang rendah, kemampuan baca tulis yang kurang, mayoritas masyarakat pedesaan irrasional. Selain itu pengguna media rakyat juga mempunyai tujuan, yaitu membangun hubungan kedekatan, pangkat/transaksi sosial, pengakuan/penghargaan identitas diri, serta menghilangkan pembatas sistem tradisional dan modern.

Hal yang harus diperhatikan dalam menggunakan media rakyat pada pembangunan: Isu krusial yang ada adalah menyisipkan pesan-pesan yang berorientasi pembangunan pada isi sebuah media rakyat. Raganath (1980) dalam Dilla (2007) menyarankan bahwa karakter yang mengikuti setiap bentuk media rakyat harus didasarkan pada kategori bentuk (audio,visual, audiovisual), isi tematis, fleksibilitas, dalam mengkomodasi pesanpesan pembangunan, dan konteks kebudayaaan. Berkaitan dengan fleksibilitas, dapat dikategorikan sebagai media rakyat yang kaku (bersifat ritual dan sangat religius), semi-fleksible (masih memberikan kesempatan yang terbatas untuk menyelipkan pesan asing).

c. Menyempitkan jurang pemisah melalui redundansi

Dapat dibuktikan bahwa munculnya kesenjangan pengetahuan dan keterampilan pada khalayak diakibatkan oleh informasi yang dapat diakses, media pun dapat meningkatkan ketidakseimbangan sosial ekonomi diantara para audiennya. Dengan adanya komunikasi pembangunan, maka dapat mempersempit adanya pemisah antara masyarakat yang masih tradisional dan modern.

d. Mengulang bias pro-literacy

Beberapa strategi dalam penelitian komunikasi pembangunan tentang cara menanggulangi para audiens illeeterate, yaitu dengan mengkomunikasikan melalui kesejahteraan sosial formal dan informal. Adanya biar pro-literacy telah menjadi penghalang terhadap penyebaran informasi pada audiens illerate dan proliterate. Strategi komunikasi pembangunan yang berorientasi kepada kebutuhan rakyat perlu mengidentifikasi dan mengulangi bias pro-literacy sebagai keseluruhan pendekatan pembangunan.

e. Memaksimalkan Peran Komunikator sebagai Agen Pembangunan

Langkah ini ditempuh dengan melibatkan berbagai pihak yang berkompeten dan berkepentingan (stakeholder) sehingga 
pembangunan dapat berjalan sesuai dengan tujuan. Melalui agen pembangunan yang berkapabilitas tinggi, akan menyebabkan perbaikan dalam pembangunan tersebut, karena semakin tinggi kompetensi seseorang, maka akan lebih banyak memberikan pengaruh, daripada orang yang mempunyai kompetensi rendah.

f. Menyusun pesan berorientasi kepada audiens

Tugas seseorang agen pembangunan yaitu menyampaikan motivasi, agar semua audiens tergerak untuk melakukan pembangunan. Pesan yang disampaikan kepada audiens harus dapat dipahami bersama dan membangun. Dalam menyampaikan pesan, agen haruslah mengerti keadaan audiens, dan memilih cara yang tepat dalam penyampaian pesan tersebut, agar pesan akan lebih mudah diterima. Sehingga dalam strategi ini benar-benar mementingkan audiens, baik pesan maupun cara penyampaiannya.

g. Memanfaatkan jasa teknologi komunikasi

Saat ini, teknologi telah benar-benar merambah kehidupan masyarakat. demikian juga perkembangan teknologi seiring dengan dinamika perkembangan. Pemanfaatan jasa teknologi pada perubahan sosial sangat membantu kegiatan komunikasi pembangunan. Penggunaan teknologi tersebut sudah banyak digunakan, namun dalam pelaksanaannya, harus diimbangi dengan kebijakan lokal serta kearifan, agar tidak keluar dari batas-batas kebijaksanaan (melupakan Local Wisdom).

\section{Metode Penelitian}

Adapun metode dalam penelitian ini adalah metode kualitatif yang bersifat deskriptif. Metode penelitian kualitatif ini sering disebut metode penelitian naturalistik karena penelitiannya dilakukan pada kondisi yang alamiah (natural setting);metode penelitian ini digunakan untuk meneliti pada kondisi obyek yang alamiah, (sebagai lawannya adalah eksperimen) dimana peneliti sebagai instrumen kunci, teknik pengumpuln data dilakukan secara gabungan, analisis data bersifat induktif $\mathrm{dn}$ hasil penelitian kualitatif lebih menekankan makna dari pada generalisasi.Obyek dalam penelitian kualitatif adalah obyek yang alamiah, atau natural setting. Kriteria data dalam penelitian kualitatif adalah data yang pasti. Data yang pasti adalah data yang sebenarnya terjadi sebagaimana adanya, bulkan data yang sekedar terlihat, terucap tetapi data yang mengandung makna dibalik yang terlihat dan terucap (Sugiyono, 2016:1-3). 
Penelitian deskriptif adalah sebuah penelitian yang memaparkan dan peristiwa yang terjadi. Metode deskriptif dapat diartikan sebagai prosedur pemecahan masalah yang akan diteliti, dengan menggambarkan keadaan objek penelitian pada saat sekarang, berdasarkan fakta yang tepat atau bagiamana adanya. Pada hakekatnya, penelitian deskriptif mengumpulkan data secara keseluruhan. Karakteristik data diperoleh dari survei langsung, wawancara, dan mencari wacana yang relevansi dengan objek penelitian. Ciri lain metode deskriptif ialah titik berat pada observasi dan suasana ilmiah. Disini peneliti hanya bertindak sebagai pengamat, yang hanya membuat kategori perilaku, mengamati gejala dan mencatat ke dalam buku observasi. Dengan suasana yang dimaksudkan bahwa peneliti terjun langsung kelapangan (Jalaluddin, 1998:56)

\section{Hasil Penelitian dan Pembahasan}

\section{Komunikasi Pembangunan Pemerintah Gampong Pelita Sagoup Jaya}

Berdasarkan observasi yang penulis lakukan di Gampong Pelita Sagoup Jaya. Komunikasi pembangunan dalam perencanaan dan pengelolaan dana APBG yang dijalankan oleh Pemerintah Gampong sudah dilakukan dengan ketentuan yang berlaku. Pelaksanaan ini tentunya berjalan dengan efektif karena komunikasi yang dibangun pemerintahan gampong dengan masyarakat berjalan dengan baik. Komunikasi yang baik akan melahirkan suatu kesepahaman dan kebijakan yang menguntungkan antara pengirim informasi dengan penerima informasi.

Secara sederhana komunikasi pembangunan adalah suatu aktivitas pertukaran pesan secara timbal balik diantara semua pihak yang terlibat dalam perencanaan pembangunan dan pengelolaan dana APBG. Dalam komunikasi pembangunan terjadi pengiriman informasi, penerimaan informasi dan pertukaran informasi pembangunan dalam proses komunikasi. Dalam aktivitas sehari-hari, komunikasi tentang pembangunan sudah dilaksanakan oleh pemerintahan gampong Pelita Sagoup Jaya, Kecamatan Indra Makmu. Komunikasi mengenai pembangunan yang dijalankan oleh pemerintahan gampong Pelita Sagoup Jaya merupakan sarana bagi pemerintahan gampong untuk menyalurkan informasi terkait 
tentang kondisi, permasalahan, kebutuhan masyarakat serta perkembangan mengenai pembangunan yang terjadi di gampong.

Dalam penelitian ini, komunikasi pembangunan dikhususkan pada komunikasi pembangunan pemerintahan gampong dalam perencanaan dan pengelolaan dana Anggaran Pendapatan dan Belanja Gampong (APBG). Berdasarkan hasil penelitian, dalam penyampaian informasi tentang pembangunan kepada masyarakat yang berkaitan dengan perencanaan pengelolaan APBG tersebut, Pemerintah gampong Pelita Sagoup Jaya melakukan komunikasi secara langsung dan komunikasi dengan media. Sebagaimana wawancara penulis dengan Bapak Sartiman (50) Selaku Keuchik Gampong Pelita Sagoup Jaya, beliau mengatakan bahwa:

“...kita melakukan komunikasi langsung kepada masyarakat melalui MUSDUS (Musyawarah Dusun), MUSREMBANG (Musyawarah Rencana Pembangunan Gampong), dan rapat umum mengenai kegiatan apa yang akan kita rencanakan dan berapa anggaran yang akan kita terima setiap tahunnya dan MUSREMBANG kita lakukan setiap tahun sekali..."(Wawancara 15 Mei 2017).

Hal ini diperkuat juga oleh Bapak Legianto (38), SH selaku Sekretaris Gampong Pelita Sagoup Jaya, bahwa

“...Setelah itu baru dibuat spanduk atau baliho APBG nya, setelah itu baru kita papangkan atau tempelkan di tempat umum dan pembangunan akan dilakukan sesuai dengan MUSREMBANG yang sudah disepakati...”(Wawancara 19 Mei 2018).

Pemerintah gampong dan masyarakat merupakan unsur yang terdapat dalam organisasi pemerintahan gampong Pelita Sagoup Jaya. Pesan dalam jaringan komunikasi pemerintahan gampong tersebut biasanya mengalir dari atas ke bawah atau dari bawah keatas atau dari tingkat yang sama atau secara horizontal. Observasi yang penulis lakukan di Gampong Pelita Sagoup Jaya terlihat bahwa arus komunikasi yang terjalin yaitu komunikasi antara pemerintah gampong dengan masyarakat, masyarakat 
dengan pemerintah gampong dan antara masyarakat dengan masyarakat.

Arus pesan dan informasi dari pemerintahan gampong yang berada pada struktur mengalir keseluruh lapisan masyarakat yang berada di bawah struktur organisasi. Pemerintah gampong sebagai pemegang kekuasaan di pemerintahan gampong memiliki tugas, tanggung jawab, dan wewenang, maka komunikasi yang digunakan menyampaikan pesan-pesan informasi yang berkenaan dengan seluruh kegiatan gampong khususnya kegiatan pembangunan.

Selain itu komunkasi yang terjadi ketika masyarakat mengirim pesan kepada pemerintah gampong juga sangat perlu dilakukan, karena didalam komunikasi pembangunan masyarakat dapat berpartisipasi dan turut serta memberikan usulan, ide-ide, atau saran maupun pertanyaan terkait dengan perencanaan pembangunan dalam pengelolaan dana Anggaran Pendapatan dan Belanja Gampong (APBG).

Komunikasi sebagai suatu proses dimana seseorang menyampaikan pesannya, maka komunikasi pembangunan dalam perencanaan pengelolaan dana APBG di Gampong Pelita Sagoup Jaya merupakan penyampaian pesan atau informasi mengenai perencanaan pembangunan dan pengelolaan anggaran pembangunan dan belanja gampong tersebut antara pemerintah gampong dengan masyarakat. Sebagaimana wawancara penulis dengan Bapak Sartiman (50) Selaku Keuchik Gampong Pelita Sagoup Jaya, beliau mengatakan bahwa:

“...Pertama sekali mulai dari tahun 2017, untuk penyampaian informasi sudah diwajibkan mempunyai spanduk rencana pembangunan dan anggaran APBG dan alhamdulillah itu tidak menimbulkan permasalahan. Kedua kita melakukan komunikasi langsung kepada masyarakat melalui MUSDUS (Musyawarah Dusun), MUSREMBANG (Musyawarah Rencana Pembangunan Gampong), dan rapat umum mengenai kegiatan apa yang akan kita rencanakan dan berapa anggaran yang akan kita terima setiap tahunnya dan MUSREMBANG kita lakukan setiap tahun sekali..."(Wawancara 15 Mei 2017). 
Hal ini diperkuat juga oleh Bapak Legianto (38) selaku Sekretaris Gampong Pelita Sagoup Jaya, bahwa:

“...Komunikasi pembangunan yang dijalankan pertama pemerintah gampong melakukan MUSDU(Musyawarah Dusun), setelah MUSDU selesai lanjut ke MUSREMBANG Gampong setelah program pembangunan yang diajukan atau diusulkan masyarakat selesai dipaparkan maka akan di tarik kesimpulan apa yang akan disepakati untuk dilakukan pembangunan lebih dulu. Setelah dimusyawarahkan apa yang disepakati dan dibuat berita acara kita naikkan usulan, kemudian setelah dinaikkan usulan kita sesuaikan dengan dana gampong...'(Wawancara 19 Mei 2018).

Dari hasil wawancara diatas menunjukkan bahwa pemerintahan gampong selalu menyampaikan setiap informasi pembangunan kepada masyarakat dan melibatkan masyarakat pada setiap perencanaan dan kegiatan pembangunan yang akan dibangun di Gampong Pelita Sagoup Jaya.

Pemerintah gampong selaku tokoh yang dipercaya untuk mengelola segala permasalahan pada pembangunan dan pemerintahan gampong. Maka sudah sepatutnya pemerintah gampong untuk menyampaikan setiap informasi yang berkenaan dengan perencanaan dan pengelolaan pada dana anggaran pendapatan dan belanja gampong (APBG). Terlebih masalah komunikasi pembangunan dari pemerintah kepada masyarakat sehingga masyarakat dapat ikut berpartisipasi terhadap jalannya proses pembangunan kedepan nantinya. Sebagaimana disampaikan oleh Bapak Sartiman (50) selaku keuchik gampong Pelita Sagoup Jaya, bahwa:

“...kami disini memaparkan dan memberi pemahaman kembali bahwa setiap kegiatan yang dilakukan pemerintah gampong pembangunan yang dijalankan semua ini dari kita untuk kita makanya kita buat semaksimal mungkin. Alhamdulillah berjalannya waktu masyarakat memenuhi antusias untuk kegiatan pembangunan desa masyarakat hampir sepenuhnya mendukung, bahkan mereka tidak merasa keberatan jika ada asset mereka dijadikan jalan atau kepentingan 
bersama lainnya. Hampir seluruhnya mendukung..."(Wawancara 15 Mei 2018).

Komunikasi yang terjadi antara masyarakat dengan pemerintah gampong sebagai upaya yang dilakukan dalam menyampaikan pesan, ide, gagasan serta informasi terkait dengan pembangunan. Sehingga proses komunikasi harus benar-benar terjalin dengan sebaik-baiknya agar tidak terjadi kesalahpahaman antara pemerintah gampong dengan masyarakat, terlebih masalah yang berhubungan dengan perencanaan pengelolaan dana APBG pada pembangunan di gampong.

Wawancara dengan Ibu Satiyah (45) salah satu masyarakat gampong Pelita Sagoup Jaya menyampaikan bahwa:

“...Untuk merancang pembangunan setiap lorong atau dusun mereka melakukan musyawarah secara terbuka dan langsung melibatkan semua masyarakat untuk membahas apa-apa saja yang akan dibangun, setelah sepakat bersama mereka akan mengajukan ke kepala desa di musyawarah desa. saya lihat juga pemerintahan gampongnya baik dan dekat dengan masyarakat.."(Wawancara 19 Mei 2018)

Komunikasi yang dilakukan pemerintah gampong Pelita Sagoup Jaya tentang pembangunan terjalin melalui komunikasi dari pemerintah gampong kepada masyarakat dan sebaliknya dari masyarakat kepada pemerintah gampong sehingga komunikasi yang terjdi dengan cara timbal balik. Penyampaian informasi pembangunan yang dijalankan pemerintah gampong akan efektif jika menggunakan strategi dalam berkomunikasi. Seperti yang disampaikan oleh Bapak Suliadi (37) selaku kaur pemerintahan Gampong Pelita Sagoup Jaya menyatakan bahwa:

“...Alhamdulillah untuk saat ini pemerintah gampong sudah semaksimal mungkin melayani masyarakat dengan baik. Untuk penyampaian informasi tentang pembangunan kepada masyarakat pemerintah gampong mengedepankan musyawarah, komunikasi secara langsung dan melalui media spanduk agar tidak terjadi kesalah pahaman antara pemerintah gampong dengan masyarakat gampong.."(Wawancara 18 Mei 2018). 
Pemerintah gampong memang sudah seharusnya menyampaikan setiap informasi kepada masyarakat dengan cara apapun, karena pemerintah gampong Merupakan tokoh masyarakat yang dipercaya untuk mengelola pemerintahan gampong dengan sebaik-baiknya. Sehingga komunikasi harus benar-benar terjadi dengan baik antara perangkat gampong dengan masyarakat.

Cara penyampaian informasi mengenai pembangunan terkait dengan perencanaan pengelolaan dana anggaran pendapatan dan belanja gampong di gampong Pelita Sagoup Jaya, secara umum terjadi ketika mengadakan musyawarah. Dalam musyawarah tersebut pemerintah gampong Pelita Sagoup Jaya menyampaikan informasi kepada masyarakat baik itu petunjuk, kebijakan maupun jumlah anggaran yang dikeluarkan/didapatkan untuk pelaksanaan pembangunan gampong. Berikut ini Bapak Jumino (55) selaku Kaur Pembangunan di Gampong Pelita Sagoup Jaya menambahkan bahwa:

“...Pemerintah gampong selalu melakukan sharing
dengan masyarakat, dan kita selalu mengadakan
musyawarah dusun, musyawarah gampong, membahas
pembangunan dan dana gampong dan kita gunakan dana
gampong ini untuk kebutuhan yang dibutuhkan
masyarakat gampong..."(Wawancara 17 Mei 2018).

Selanjutnya dalam mencapai keberhasilan komunikasi antara pemerintahan gampong dengan masyarakat gampong. Setiap masyarakat perdusun akan melakukan musyawarah terlebih dahulu untuk mengambil keputusan tentang perencanaan pengelolaan dana APBG terhadap pembangunan, hal ini dilakukan agar komunikasi yang terjalin nantinya tidak membawa dampak yang negatif terhadap pendapat dari masyarakat dusun lainnya. Sebagaimana wawancara penulis dengan Bapak Legianto (38) selaku Sekretaris Gampong di Gampong Pelita Sagoup Jaya beliau menyatakan bahwa:

“...Setiap kegiatan MUSREMBANG setiap warga berhak untuk mengajukan menentukan usulan, yang sesuai dengan keputusan apa yang sangat mendesak duluan dan sudah disepakati ketika MUSDUS. Semua 
masyarakat mengusulkan semua tapi disini kita lihat dan kondisikan dengan dana gampong dan kebutuhan yang sangat mendesak barulah terjadi pembangunan gampong...”( Wawancara 19 Mei 2018).

Hal ini dapat diperkuat oleh Bapak Suliadi (37) selaku Kaur Pemerintahan di Gampong Pelita Sagoup Jaya, bahwa:

“...selama ini kita menyelesaikan permasalahan pembangunan menggunakan musyawarah. Jadi di situ ada keterbukaan antara pemerintahan gampong dengan masyarakat. Strateginya kami disini mengumpulkan tokoh-tokoh gampong, perangkat gampong, kaduskadus. Setelah itu kita terangkan secara transparan. Kemudian kadus-kadus tersebut menyampaikan kemasyarakat tiap-tiap dusun bahwasanya inilah yang akan kita kelola dan kita bangun..."(Wawancara 17 Mei 2018).

Didalam kehidupan bermasyarakat pada dasarnya manusia merupakan makhluk sosial, artinya mereka tidak bisa hidup sendiri dalam sebuah lingkungan. Sehingga mereka membutuhkan orang lain untuk menjalin komunikasi yang baik dan efektif dimana nanti akan terjadinya pertukaran pesan antara masyarakat satu dengan masyarakat lainnya. Oleh karena itu kontak sosial dalam bentuk komunikasi pembangunan pemerintahan gampong Pelita Sagoup Jaya tidak bisa dihindari dalam berbagai aktivitas. Berikut pemaparan dari Bapak Suparno (54) selaku masyarakat Gampong Pelita Sagoup Jaya:

“...Komunikasi pembangunan yang dijalankan oleh pemerintah gampong sudah bagus, mereka terbuka ketika musyawarah dan pembangunannya yang dijalankan ada Nampak buktinya atau di buat papan proyek dan ketika ada kegiatan pembangunan, juga masyarakat disini dilibatkan dalam kegiatan pembangunan itu dan masyarakat yang jadi pekerjanya kemudian di bayar oleh pemerintah gampong...”(Wawancara 16 Mei 2018) 
Komunikasi yang baik akan terjalin hubungan yang baik pula, terlebih dalam sebuah komunikasi pemerintah gampong harus mampu memimpin masyarakat gampong dengan berbagai karakternya. Proses komunikasi pembangunan yang dijalankan oleh pemerintah Gampong Pelita Sagoup Jaya kepada masyarakat ialah komunikasi secara langsung atau komunikasi interpersonal dengan tujuan untuk menyampaikan informasi, menerima saran/usulan dari masyarakat, untuk merubah sikap, membentuk pendapat mengurangi kecurigaan yang timbul karena salah informasi dan mencegah kesalahpahaman karena kurang informasi dan mempersiapkan masyarakat untuk menyesuaikan diri dan turut berpartisipasi dalam jalannya proses pembangunan di Gampong Pelita Sagoup Jaya. Berdasarkan hasil observasi yang dilakukan di lapangan, penulis menemukan adanya strategi komunikasi pembangunan yang digunakan oleh pemerintah gampong strateginya adalah dengan membentuk musyawarah/rapat dan melakukan pembinaan, perencanaan, pengawasan, pelatihan serta pemberdayaan.

\section{Pembahasan}

Komunikasi merupakan proses penyampaian pesan dari komunikator kepada komunikan melalui media seperti apa yang akan digunakan dan memunculkan pengaruh/efek tertentu. Jadi, komunikasi pembangunan merupakan segala upaya dan cara, serta teknik penyampaian gagasan, dan keterampilan-keterampilan pembangunan yang berasal dari pihak yang memprakarsai pembangunan dan ditujukan kepada masyarakat luas. Kegiatan tersebut bertujuan agar masyarakat yang dituju dapat memahami, menerima, dan berpartisipasi dalam melaksanakan gagasangagasan yang disampaikan (Nasution, 2007:81-105-106).

Dengan melihat hasil penelitian ini melalui Teori Difusi Inovasi, sangat jelas bahwa di dalam komunikasi antara pemerintah gampong dan masyarakat dibutuhkan suatu proses bagaimana suatu inovasi dikomunikasikan melalui saluran-saluran sepanjang waktu pada sekelompok anggota dari sistem sosial. dengan aspek tersebut yang nantinya akan membantu pemerintahan gampong dan masyarakat agar komunikasi yang terjalin nantinya berlangsung dengan baik. Selain itu penelitian ini menggunakan teori pembangunan yang berpusat pada rakyat, pembangunan yang dijalankan oleh pemerintah gampong telah mempusatkan fokus 
pembangunannya untuk masyarakat agar pembangunan yang dilakukan oleh pemerintah gampong merata dengan baik.

Komunikasi yang tepat dan efektif tidak terjadi secara serta merta saja melainkan memiliki cara-caranya. Adapun cara berkomunikasi yang tepat yaitu, komunikasi secara lansung untuk mengharapkan efek perubahan tingkah laku dari peserta komunikasi dan komunikasi melalui media yang disampaikan oleh komunikator. Dari hasil penelitian yang peneliti lakukan bahwa komunikasi pembangunan yang terjalin antara pemerintah gampong dan masyarakat di Gampong Pelita Sagoup Jaya ini menggunakan komunikasi secara langsung (musyawarah) dan menggunakan media. Pemerintah gampong lebih banyak menggunakan komunikasi secara musyawarah/langsung agar inforrmasi yang disampaikan atau informasi yang dapat diterima oleh khalayak akan mendapatkan respon timbal balik dalam penyampaian pesan.

Strategi komunikasi pembangunan dari komunikator sangatlah penting untuk mencapai tujuan dari komunikasi pembangunan itu sendiri. mengingat di Gampong Pelita Sagoup Jaya yang bertindak sebagai komunikator adalah pemerintah gampong dan perangkatnya. Strategi komunikasi pemerintah gampong dalam menginformasikan tentang pembangunan harus sedemikian rupa sehingga komunikator sebagai pelaksana dapat segera mengadakan perubahan apabila ada suatu faktor yang mempengaruhi. Faktor yang mempengaruhi biasanya terdapat pada sikap komunikator, komponen media sehingga efek yang diharapkan tak sesuai.

Dari hasil penelitian peneliti di Gampong Pelita Sagoup Jaya dari 4 strategi komunikasi pembangunan yang ada dalam landasan teori, disini peneliti hanya menemukan 3 strategi komunikasi pembangunan yang digunakan oleh pemerintah gampong Pelita Sagoup Jaya, yaitu:

1. Strategi berdasarkan media

Pemerintah gampong Pelita Sagoup Jaya melakukan strategi komunikasi pembangunan melalui media seperti spanduk/baliho, agar mempermudah pemerintah gampong menyampaikan informasi terkait dengan dana anggaran pendapatan dan belanja gampong dan informasi apa saja yang mengenai dengan gampong. Jadi, dengan adanya baliho tersebut tentunya akan mempermudah 
masyarakat yang ingin mengetahui informasi terkait dengan danadana pembangunan yang ada di gampong.

Pemerintah gampong dalam menggunakan strategi komunikasi pembangunan berdasarkan media ini belum bisa dikatakan efektif, karena belum semua masyarakat memiliki minat baca dan keingintahuan tentang jumlah anggaran tahunan gampong dan informasi lainnya. Jadi, hanya sebagian kecil saja masyarakat di Gampong Pelita Sagoup Jaya yang membaca dan memerhatikan isi pesan yang ada di baliho tersebut.

2. Strategi Desain Intruksional

Pada strategi ini berorientasi pada rencana dan sistem. Satretegi komunikasi desain intruksional yang dilakukan oleh pemerintah gampong adalah dengan mengubah pola pikir dan perilaku dari masyarakat seperti melakukan musyawarah, pelatihan, sosialisasi, kegiatan keterampilan, kegiatan pendidikan, pemberdayaan dan kegiatan lain agar masyarakat bisa menikmati dan mengkreasikan hasil dari kerajinan dan pelatihan yang dijalankan oleh pemerintah gampong. Dalam strategi ini sering tejadi proses komunikasi secara langsung atau musyawarah dalam perencanaan komunikasi kepada masyarakat untuk memberi saran, masukan atau ide-ide terkait dengan perencanaan pembangunan kepada pemerintah gampong. Dengan adanya komunikasi antara pemerintah gampong dengan masyarakat, maka masyarakat akan turut berpartisipasi dan ikut serta dalam jalannya proses pembangunan yang ada di Gampong Pelita Sagoup Jaya.

3. Strategi Partisipatori

Pada strategi ini, banyaknya informasi yang didapat dan dipelajari seseorang dari program komunikasi pembangunan tidaklah begitu penting, tetapi disini yang lebih penting pada pengalaman keikutsertaan sebagai seseorang dalam proses berbagi pengetahuan dan keterampilan.

Strategi komunikasi partisipatori yang dilakukan pemerintah gampong dalam berkomunikasi dengan masyarakat adalah pemerintah gampong turun langsung ke lapangan untuk melihat perkembangan pembangunan dan berkomunikasi dengan masyarakat gampong terkait dengan pembangunan yang ada di Gampong Pelita Sagoup Jaya. Masyarakat gampong juga turut serta berpartisipasi dan mengawasi dalam pembangunan yang ada di gampong Pelita Sagoup Jaya, hal ini terlihat dimana ketika pembangunan terjadi pekerja yang mengerjakan pembangunan 
tersebut merupakan masyaakat gampong tersebut. Antara pemerintah gampong dan masyarakat sama-sama saling bekerjasama dalam membangun dan mengawasi pembangunan di Gampong Pelita Sagoup Jaya.

Berdasarkan observasi yang dilakukan peneliti selama ini diketahui bahwa hambatan komunikasi yang dihadapi oleh pemerintah gampong dalam menginformasikan pesan-pesan pembangunan terutama dalam hal perencanaan dan pengelolaan dana anggaran pendapatan dan belanja gampong adalah hambatan komunikasi yang meliputi kepentingan, prasangka, dan motivasi. Selain berdasarkan hambatan komunikasi ada hambatan lainnya yaitu berupa persepsi masyarakat yang berbeda, banyaknya permintaan pembangunan dari masyarakat, dan ketidaksepemahaman antara pemerintah gampong dan masyarakat di Gampong Pelita Sagoup Jaya.

\section{Penutup}

Komunikasi pembangunan yang dilakukan antara pemerintah gampong dan masyarakat di Gampong Pelita Sagoup Jaya, Kec.Indra Makmu, Kab.Aceh Timur merupakan komunikasi yang dilakukan secara langsung dan menggunakan media. Komunikasi secara langsung yang dilakukan oleh pemerintah gampong seperti musyawarah dusun, musyawarah gampong dan rapat-rapat internal. Sedangkan komunikasi bermedia yang dilakukan oleh pemerintah gampong seperti pemasangan baliho/spanduk, papan proyek, dan pengumuman melalui speaker mesjid. Strategi yang digunakan oleh pemerintah gampong dalam mengkomunikasikan tentang pembangunan adalah dengan menggunakan strategi komunikasi berdasarkan media seperti media spanduk, strategi desain intruksional seperti pembinaan masyarakat gampong dan strategi partisipatori seperti gotong royong dan lainnya.

\section{Daftar Pustaka}

Ardianto, Elvinaro. (2011). Metedologi Penelitian Untuk Public Relations Kuantitatif dan Kualitatif. Bandung: PT.Remaja Rosdakarya. 
(2012). Komunikasi Massa Suatu

Pengantar. Bandung: Simbiosa Rekatama Media.

Dilla, Sumadi. (2007). Komunikasi Pembangunan:pendekatan terpadu. Bandung: Simbiosa Rekatama Media.

Effendy, Onong Uchjana . (2003). Ilmu, Teori, dan Filsafat Komunikasi.Bandung: Citra Aditya Bakti.

Harun Rochajat dan Ardianto, Elvinaro. (2012). Komunikasi pembangunan dan Perubahan Sosial: Perspektif Dominan, Kajian Ulang, dan Teori Kritis.Jakarta: Rajawali Press

Korten, C. David. (2001). Menuju Abad Ke-21. Jakarta:Yayasan Obor Indonesia.

Moleong, (2011). Metode Penelitian Kualitatif Edisi Revisi. Bandung: PT. RemajaRosdakarya

Nasution, Zulkarimen. (2007). Komunikasi Pembangunan Pengenalan Teori dan Penerapannya. Jakarta: PT RajaGrafindo Persada

Rakhmat, Jalaludin. (1998). Metode Penelitian Komunikasi. Bandung: CV Remaja Karya.

Rogers. M. Everett. 1971. Diffusion of Innovations: Third Edition. New York: The Free Press.

Sanusi M Syarif. (2010). Gampong dan Mukim di Aceh Menuju Rekonstruksi Pasca Tsunami. Bogor : Pustaka Latin.

Sugiyono.(2012).Metode penelitian kuantitatif dan kualitatif,dan $R$ $\& D$. Bandung: Alfabeta.

(2016). Memahami Penelitian Kualitatif. Bandung:Alfabeta.

Suwandi dan Basrowi. (2008). Memahami Penelitian Kualitatif. Jakarta: Rineka Cipta.

Sumber lain:

64

Jurnal Jurnalisme Volume 7 No. 1 Edisi April 2018 
Afdilah, Nur Hasnah (2014). Strategi Komunikasi Pembangunan Dalam Community Development (Studi Deskriptif Kualitatif Pada Seks Keberhasilan dan Lingkungan Hidup Dusun Sukunan Banyuraden Gamping Sleman Yogyakarta. Universitas Islam Negeri Sunan Kalijaga Yogyakarta.

Drian. (2013). Pengertian Media Komunikasi, Fungsi dan Jenisnya.

[Online].http://pengertianedefinisi.com/pengertianmedia-komunikasi-fungsi-dan-jenisnya/. [ 7 Desember 2017]

Peraturan Bupati Aceh Timur Nomor 32 Tahun 2014 Tentang Alokasi Dana Gampong Dan Alokasi Bagian Dari Hasil Pajak Daerah Dan Retribusi Daerah Serta Tata Cara Pengelolaan Dan PertanggungJawaban.

Peraturan Bupati Aceh Timur Nomor 32 Tahun 2015 Tentang Penghasilan Bagi Keuchik Dan Perangkat Gampong.

Maharani, Yasnita (2012). Strategi Komunikasi Pembangunan Dalam Meningkatkan Eksistensi Pasar Tradisional (Study Deskriptif Kualitatif Tentang Pelaksanaan Strategi Dinas Pengelolaan Pasar (DPP) Pemerintahan Kota Surakarta Dalam Meningkatkan Eksistensi Pasar Tradisional Nasukan, Banjarsari). Universitas Muhammdiyah Surakarta. Surakarta.

Pramudyandari, Zulfiah (2016). Strategi Komunikasi Pembangunan Dalam Mewujudkan Visi Misi Organisasi (Studi Deskriptif Kualitatif Dalam Bidang Kesejahteraan Sosial Pemerintah Pada Kabupaten Purwakarta Periode 2013-2018). Universitas Islam Negeri Sunan Kalijaga. Yogyakarta.

RPJM Gampong Pelita Sagoup Jaya, Kecamatan Indra Makmu, Kabupaten Aceh Timur. 2017-2021

Undang- Undang Nomor 11 Tahun 2006 Tentang Pemerintahan Aceh 